\title{
O POSTSTRUKTURALISTIČKOJ TEORIJI DISKURSA KROZ RASPRAVU O UVOĐENJU POJMA 'BRAK' U HRVATSKI USTAV
}

SANJA ĐURIN

Institut za etnologiju i folkloristiku

10000 Zagreb, Šubićeva 42

sdurin@ief.hr

(iD) orcid.org/0000-0002-9557-1118
DOI: $10.17234 /$ SEC.29.12

Izvorni znanstveni rad

Primljeno: 7. 7. 2016.

Prihvaćeno: 7. 9. 2017.

Ovaj rad nalazi se u otvorenom pristupu i može se distribuirati u skladu s odredbama licencije CC BY-NC-ND 4.0 HR

Poststrukturalistička teorija diskursa kao koncept i metodologija, na mala vrata, sramežljivo i još uvijek nailazeći na odbijanje, ulazi u humanističke i društvene znanstvenoistraživačke krugove u Hrvatskoj. Nakon pregleda razvoja teorije diskursa, ovim će se radom kroz opis primjera diskurzivne borbe oko uvođenja definicije braka u hrvatski Ustav 2013. godine čitatelju nastojati približiti osnovne ideje poststrukturalističke teorije diskursa te njezine slabe točke. U članku ćemo uputiti i na to da je uz diskurzivnu borbu u slučaju uvođenja definicije braka u Ustav riječ i o pokušaju pritiska na biopolitiku države i o opasnoj biopolitičkoj borbi usmjerenoj protiv gay osoba.

Ključne riječi: poststrukturalistička teorija diskursa, brak, referendum, Ustav Republike Hrvatske, Zakon o životnom partnerstvu, biopolitika

\section{RAZVOJ TEORIJE DISKURSA ${ }^{1}$}

Sam pojam diskursa primarno se javlja u okvirima lingvistike gdje je diskurs jezična jedinica veća od rečenice, a koju definira postojanje bilo kakve semantičke zavisnosti među njezinim dijelovima (Škiljan 1980). No, nije samo pojam diskursa ono što teorija diskursa nasljeđuje od lingvistike. Teoretičari diskursa uočili su, kao i brojni sociolingvisti, da se u procesima

\footnotetext{
${ }^{1}$ Ovaj rad nastao je u okviru projekta Hrvatske zaklade za znanost, pod naslovom City-making: space, culture and indentity / Stvaranje grada: prostor, kultura i identitet (br. 2350), voditeljice dr. sc. Jasne Čapo Žmegač. Više informacija o projektu: www. citymaking.eu.
} 
društvenih transformacija jezik (odnosno govor, kao materijalizacija i manifestacija jezika) i politika neprestano isprepliću i stoga je njihov fokus na jezičnim praksama: kako se one koriste u borbama za političku dominaciju. Kao što je ustvrdio lingvist i utemeljitelj strukturalizma u lingvistici Ferdinand de Saussure (ibid.), jezik je sustav znakova čije je značenje arbitrarno i promjenjivo, pa stoga ima manipulativnu moć (vidi: Škiljan 1988, 1998; Ivas 1988; Barthes 1979; Eco 1973). Društveni i politički događaji mijenjaju naš vokabular, a dvosmislenost koju omogućuje jezik kao arbitrarni sustav znakova i retoričke vještine olakšavaju probijanje novih političkih strategija i projekata (Torfing 2005:5).

Ideja diskursa ucrtala je putmnogim analitičkim metodama i teorijama, npr. analizi sadržaja, konverzacijskoj analizi, diskurzivnoj psihologiji, kritičkoj lingvistici koja je velikim dijelom zastupljena na Sveučilištu East Anglia te kritičkoj analizi diskursa (critical discourse analysis - CDA) koju posebno razvija Norman Fairclough (ibid.:5-6). Stoga je i sam pojam diskursa danas često u upotrebi, a zbog velikog broja značenja kojima je tijekom vremena punjen, nemali broj puta njegova upotreba dovodi i do nesporazuma među sugovornicima (posebno je čest slučaj da se diskurs izjednačuje s javnim politikama). Teoretičar koji je na velika vrata u društvenu teoriju uveo pojam diskursa jest Michel Foucault iako i u njegovu radu sam pojam diskursa tijekom vremena mijenja značenje. Kako tumači Jacob Torfing (2005:7), u ranijoj, tzv. arheološkoj fazi Foucault se ne bavi toliko samom formom ili sadržajem lingvističkih iskaza i semiotičkih praksi, nego se fokusira na pravila koja su upravljala proizvodnjom tih iskaza i praksi, odnosno što je i kako moglo biti izrečeno a što ne, te tko je mogao govoriti i u čije ime. Iako u toj fazi Foucault smatra da diskurzivna pravila određuju odnosi koji ne pripadaju diskurzivnom polju, sama pravila proizvodnje iskaza i danas su važna u analizi diskursa. ${ }^{2} \mathrm{U}$ svojoj kasnijoj, genealoškoj fazi Foucault napušta podjelu na diskurzivno i nediskurzivno polje i više se bavi odnosima moći koje oblikuju i preoblikuju određene diskurzivne forme.

${ }^{2}$ Opis metode koju koristi u svojim ranijim radovima, kao i tadašnji pristup povijesti, Foucault je iznio u svojoj knjizi Archaeology of Knowledge. London: Routledge, 2002. 
Ernesto Laclau i Chantal Mouffe razvijaju svoj koncept diskursa i cjelokupnu poststrukturalističku teoriju diskursa na ideji diskursa kao onoga koji stvara identitete i fiksira značenja, kao i na brojnim interpretativnim modelima istraživanja društva (na primjer onima koja zastupaju Jacques Derrida i Richard Rorty). Po njihovu viđenju, "Svaki je diskurs konstituiran kao pokušaj dominiranja diskurzivnim poljem" (Laclau i Mouffe 1985:112). Određeni diskurs dominira diskurzivnim poljem ako je uspio fiksirati određeno značenje (i identitete) kao neupitno, istinito, prirodno, stvarno za većinu pripadnika nekog društva.

\section{POSTSTRUKTURALISTIČKA TEORIJA DISKURSA ${ }^{3}$}

Poststrukturalistička teorija diskursa (u nastavku PTD ili teorija diskursa), kao teoretski ali i analitički model interpretacije društvenih pojava, razvija se krajem sedamdesetih godina 20. stoljeća kao rezultat nezadovoljstva tadašnjim dominantnim teoretskim modelima (Torfing 2005:1). Kako navodi sam Ernesto Laclau: “... tumačenja društvenih pojava koja su davali biheviorizam, strukturalni funkcionalizam i teorija racionalnog izbora, nisu pružala zadovoljavajuća objašnjenja novih društvenih događaja" (Laclau 2000:x). Kao odgovor na to nezadovoljstvo, velikim djelom pod utjecajem Michela Foucaulta i njegove analize diskurzivnih formi, Lacanove psihoanalize, dekonstrukcije Jacquesa Derride i semiologije Rolanda Barthesa (ibid.:x), između ostalih, Ernesto Laclau i Chantal Mouffe razvijaju alternativni pristup koji na novonastajuće sociopolitičke pojave svoga vremena gleda kao na diskurzivne konstrukte koji su u stalnim antagonističkim odnosima (ibid.:xi). Od 1982. Laclau i Mouffe razvijaju svoj koncept u okviru studijskog programa Ideologija $i$ analiza diskursa na Sveučilištu u Essexu, a 1985. godine izložili su ga u knjizi Hegemony and Socialist Strategy. Danas ga na istom Sveučilištu nastavljaju razvijati Aletta Norval, David Howarth i dr. (Howarth 2013). Iako sami autori pristupa naglašavaju da on nije zatvoren sustav s potpuno definiranim

\footnotetext{
${ }^{3}$ O poststrukturalističkoj teoriji diskursa i diskurzivnoj analizi pisali su i Senka Božić Vrbančić (2009) i Duško Petrović (2011), u svom radu koristi je i politologinja Danijela Dolenec (http://www.nsz.hr/novosti-i-obavijesti/okrugli-stolovi-i-rasprave/autorasizamkriza-liberalne-demokracije-i-iscezavanje-ljevice/, pristup 12. 5. 2017.).
} 
pravilima i kategorijama, nego istraživački program u nastajanju (Laclau 2000:xi), u posljednjih dvadesetak godina sve više istraživača u svom radu poseže za teorijom diskursa (Torfing 2005:2-5; Howarth i Stavrakakis 2000:1). Razlog tomu jest, između ostalog, u načinu istraživačkog rada koji omogućuje teorija diskursa. Ona naime dopušta mogućnost da se istraživački koncepti prilagode svakom pojedinačnom istraživanju (što generira i brojne prigovore teoriji diskursa, o čemu više u drugom dijelu ovog članka). Uvjet za takav rad jest da koncept i logika teoretskog okvira budu dovoljno otvoreni i fleksibilni da se mogu prilagoditi, deformirati i transformirati u procesu primjene na analizu određenoga društvenog događaja. Teorija diskursa teži tomu da društvene fenomene istražuje i prikazuje na inovativne načine koji se i sami formiraju tijekom svakoga pojedinačnog istraživanja i zato ona iz svoga istraživačkog procesa "isključuje esencijalističke i redukcionističke teorije društva koje često predeterminiraju rezultate istraživanja" (Howarth i Stavrakakis 2000:5) i koje su trome jer ne dopuštaju teoretsku i analitičku fleksibilnost i interdisciplinarnost. U primjeru diskurzivne analize koja bi se bavila ustavnim definiranjem braka u Republici Hrvatskoj, nedostatak fleksibilnosti istraživačkog i teoretskog okvira mogao bi dovesti do toga da, npr., u analizu uopće ne uđu ekonomski (ili neki drugi strukturalni) razlozi stvaranja pojačane podjele u društvu i diskriminacije seksualnih manjina u Hrvatskoj.

Teorija diskursa od drugih se istraživačkih modela razlikuje i po tome što se fokusira na društvene antagonizme koji nastaju u društvu ili zajednici i traži njihove uzroke unutar širega društvenog i vremenskog konteksta, traži trenutak preokreta u odnosima moći koji je doveo do razvoja određene diskurzivne prakse ili do određenoga političkog poretka. Time teorija diskursa "pomiče centar društvenih i političkih istraživanja s ontički danih objekata istraživanja na njihove ontološke uvjete mogućnosti” (Laclau 2000:xi).

Da bi detektirala antagonističke odnose u istraživanju određene društvene pojave, analiza diskursa koristi kao svoje izvore empirijske materijale i informacije kao diskurzivne forme. To znači da ona tretira širok spektar lingvističkih i nelingvističkih podataka - govore, izvještaje, manifeste, povijesne događaje, intervjue, politike, ideje, organizacije i institucije, arhive, muzeje, znanstvene i književne tekstove, film, medijske 
prikaze, javne debate - kao tekst ili pismo kako ih tumači Jacques Derrida (po kojem ne postoji ništa izvan teksta što bi tekstu davalo značenje), ${ }^{4}$ i koristi ih u analizi i interpretaciji društvenih događaja i procesa. Drugim riječima, PTD diskursom smatra sve trenutačno dostupne diskurzivne forme koje proizvode i fiksiraju značenje o nekom događaju ili pojavi u društvu i te empirijske podatke promatra kao skup značenjskih praksi koje stvaraju hegemonijski diskurs i njegovu realnost, odnosno stvaraju uvjete koji subjektu omogućuju da iskusi svijet objekta, riječi i praksi na određeni način (Howarth i Stavrakakis 2000:4).

Nakraju,PTDsvedruštvene procese promatra relacijski, kontekstualno i historicistički. Naime, društveni procesi, njihova značenja, kao i identiteti koje oni proizvode, oblikuju se kroz odnose s drugim značenjima i neki pojam razumijemo tek kada ga stavimo u odnos s drugim pojmovima; ${ }^{5}$ pojedinačna značenja ili identiteti zahtijevaju da ih se analizira u specifičnom historijskom kontekstu koji uvjetuje kako će se oni konstruirati i interpretirati i svako društveno djelovanje odvija se kroz historijski specifične diskurse. Ovakav pristup nužan je ako neku pojavu u društvu želimo analizirati i interpretirati kroz teoriju diskursa.

\section{OD REFERENDUMA O BRAKU DO ZAKONA O ŽIVOTNOM PARTNERSTVU: PRIMJER DISKURZIVNE BORBE ILI STVARANJE BIOPOLITIČKOG DRUGOG?}

Kada govorimo o ustavnoj definiciji braka u Hrvatskoj, hegemonijski diskurs koji dominira diskurzivnim poljem seksualnosti i koji je davao snagu čitavoj argumentaciji za tradicionalnu definiciju braka jest diskurs o heteroseksualnosti kao čovjekovu prirodnom obliku seksualnosti. Taj je diskurs dio dominantnoga heteronormativnog sustava vrijednosti

\footnotetext{
${ }^{4}$ Vidi Belsey 2002.

${ }^{5}$ Kao što je primijetio Derrida, svaki predmet ima svoje "konstitutivno vanjsko" koje je nužno za stvaranje njegova značenja. Nadalje, značenja koja pridajemo stvarima oko sebe stvaramo sami, nema jednoga stvarnog i pravog značenja, pa tako ni jedne objektivne istine, smatra Derrida. Stoga, umjesto da nastojimo otkriti istinu, Derrida predlaže da se zadržimo na procesima dekonstrukcije kao analize na koji su način značenja "efekt traga onoga drugog u meni” (Belsey 2002:83).
} 
koji privilegira heteroseksualnost u odnosu na druge oblike seksualnog ponašanja u zapadnjačkoj kulturi. ${ }^{6}$ No, on nije samo to. Rasprave vezane uz politike seksualnosti u Hrvatskoj koje su tema ovog članka, kao i sama heteronormativnost, istodobno se trebaju promatrati i kao sredstva biopolitičkog upravljanja populacijom koje u nekim slučajevima gay osobe općenito želi prikazati kao prijetnju opstanku društva i nacije kako u Hrvatskoj tako i u mnogim drugim zemljama. Objasnit ćemo to u nastavku ovog rada gdje ćemo kroz analizu diskurzivne borbe vezane uz politike seksualnosti u Hrvatskoj predstaviti osnovne postulate poststrukturalističke teorije diskursa i uputiti na otežanu mogućnost diskurzivne borbe kao političke akcije u situacijama kada je politički prostor gotovo podijeljen u dva antagonistička tabora i kada su političke borbe usmjerene protiv određene skupine ljudi kao bioloških subjekata (Laclau i Mouffe 1985:132).

Prvi postulat teorije diskursa jest da dominantni diskursi pokušavaju fiksirati određena značenja u društvu i uspostaviti hegemoniju. Heteroseksualnost kao dominantni oblik seksualne kulture u zapadnjačkom društvu dio je heteronormativnog sustava vrijednosti. Svaki sustav vrijednosti navodi nas da pojave i procese u društvu tumačimo na određeni način te da djelujemo na određeni način. Heteronormativni sustav jest sustav u kojem su heteroseksualni odnosi ili jedini prirodni oblik seksualnih odnosa, ili moralno superiorni, a na idiomatskoj se razini manifestiraju kroz binarnu podjelu na dva međusobno komplementarna roda. Taj se sustav reproducira kroz obrazovne institucije, obitelj, crkvu i sl. te kroz medije i kulturu. Kako postuliraju Lauren Berlant i Michael Warner (1998), heteronormativnost podrazumijeva institucije, strukture razumijevanja i prakse koje heteroseksualnost čine ne samo koherentnom nego i privilegiranom seksualnom kulturom koja fiksira brak kao vezu muškarca i žene, obitelj kao reproduktivnu zajednicu, a heteroseksualnost kao poželjan identitet $\mathrm{s}$ kojim se identificira većina građana. U takvim definicijama nereproduktivne seksualnosti i identiteti istodobno postaju

\footnotetext{
${ }^{6}$ Unastavkuovograda nećemo se baviti diskurzivnimuvjetimanastankaheteronormativnosti kao određenog sustava vrijednosti, jer je taj velik posao odrađen drugdje - između ostalog, vrlo pomno u tri sveska Povijesti seksualnosti autora Michela Foucaulta kao i u knjizi Nationalism and Sexuality: Middle-Class Morality and Sexual Norms in Modern Europe autora Georgea L. Mossea.
} 
nepoželjne devijacije i smještaju se na marginu društva zbog čega homoseksualne, aseksualne, transseksualne osobe, odnosno seksualne manjine postaju marginalizirane, uskraćene za ili lišene prava koja imaju heteroseksualni građani (poput prava na ozakonjenje veze, tj. prava na brak i prava koja proizlaze iz toga, pravo na slobodno iskazivanje svojih osjećaja u javnom prostoru držanjem za ruke, zagrljajem ili poljupcem itd.). Laclau i Mouffe (1985) takvu pojavu nazivaju "političkom i moralno-intelektualnom hegemonijom" heteroseksualnosti. No, hegemonija ni jednog diskursa nije trajna ni stalna. Poredak koji će diskurs u nekom trenutku stvoriti nije stabilna samoreproducirajuća struktura nego nestabilan sustav koji je stalno podložan političkim pokušajima narušavanja ili restrukturiranja diskurzivnog konteksta u vremenu ili kroz povijest (Torfing 2005:14). Drugim riječima, diskurs je podložan dislokaciji. Primjerom koji slijedi opisat ćemo dislokaciju dominantnog diskursa u polju ljudske seksualnosti - diskursa o heteroseksualnosti.

Kao jedan od pokušaja ${ }^{7}$ dislokacije hegemonije heteroseksualnosti u Hrvatskoj možemo promatrati događaje vezane uz politike seksualnosti od 2012. godine naovamo. S početkom je 2012. godine nova, uvjetno rečeno lijevo orijentirana vlada po svom predizbornom programu namjeravala uvesti više značajnih promjena u javne politike vezane uz biopolitičko upravljanje građanima kroz politike seksualnosti: prvi je na red trebao doći Zakon o medicinski potpomognutoj oplodnji, a osim toga raspravljalo se i o uvođenju zdravstvenog i građanskog odgoja u škole ${ }^{8}$ te o donošenju Zakona o životnom partnerstvu. Sve te intervencije u zakone (koji pokrivaju područje biopolitičkog upravljanja građanstvom) dislociraju diskurs o heteroseksualnosti čemu se, između ostalih, odupiru konzervativne struje uz podršku katoličkog klera u Hrvatskoj. Naime, brojne udruge građana vjernika u suradnji sa svećenstvom i vrhom Katoličke crkve u Hrvatskoj (u daljnjem tekstu Crkva) pokušavajuzaustaviti donošenjeZakona o medicinski potpomognutoj oplodnji u srpnju 2012. godine, tako što sakupljaju potpise

\footnotetext{
${ }^{7}$ Razni pokušaji dislokacije heteroseksualnog diskursa događaju se u svijetu u intervalima još od Stonewallske revolucije 1969. godine (vidi Dota 2011.).

${ }^{8}$ https://www.documenta.hr/assets/files/objave/2012\%2004/2012.04.06_Platforma112. pdf (pristup 10. 5. 2017.).
} 
za referendum o spomenutom Zakonu. Nakon što nije sakupljeno dovoljno potpisa za referendum o Zakonu o medicinski potpomognutoj oplodnji, sljedeći na negodovanje nailazi novi kurikulum zdravstvenog odgoja koji se trebao naći u programima osnovnih i srednjih škola iste te godine. Tada se, kao što ćemo objasniti u nastavku, u diskurzivnu borbu uključuju i novi momenti koji će u društvu stvoriti još veću podjelu među onima koji podržavaju tradicionalno razumijevanje braka, obitelji i seksualnosti i onih koji žele inkluzivnu definiciju braka.

Prije početka nove školske godine u jesen 2012. godine roditeljima su se na ulicama i u trgovinama dijelili letci Hrvatske biskupske konferencije naslova O programu zdravstvenoga odgoja u školama u kojima se roditelje upozoravalo da zdravstveni odgoj želi djeci nametnuti "svjetonazor koji niječe i zanemaruje neke temeljne općeljudske vrijednosti vezane za spolnost" iželi djecu indoktrinirati “rodnom ideologijom" (izletka). 'Rodna ideologija' jest pseudoznanstveni koncept koji je stvorila Katolička crkva, a posebno ga u vrijeme svoje papinske službe koriste bivši papa Benedikt XVI. i sadašnji papa Franjo. Pojmom 'rodne ideologije' Katolička crkva želi obezvrijediti "postignuća feminističkih, LGBTI i ljudsko-pravaških pokreta, kao i korpus akademskog znanja koji dekonstruira, uglavnom biološki utemeljene pretpostavke o kategorijama spola, roda i seksualnosti" (Hodžić i Bijelić 2014:5), jer čitav taj korpus znanja i postignuća tumači kao prijetnju tradicionalnoj obitelji, pa i čitavom čovječanstvu. Zbog toga i kardinal Bozanić na božićnoj misi 2012. godine negoduje što Crkva nije pozvana na dijalog kod izrade kurikuluma zdravstvenog odgoja, uspoređujući takav postupak Vlade s retorikom "koja seže duboko u vrijeme nedavne prošlosti”. ${ }^{10}$ Relacijom između sadašnjosti i nedavne prošlosti (gdje se pritom misli na

\footnotetext{
${ }^{9}$ http://www.hbk.hr/1_z_odgoj.pdf (pristup 9. 5. 2017.).

10 "Krist se rodio radi čovjeka i Crkva postoji da bi bila u službi čovjeka. Stoga nas čudi kad se iznova ponavljaju već poznate parole o tome kako se Crkva miješa u područja o kojima ona nema što reći, a govori se o odgoju mladog čovjeka u našim školama. Čega se sve zadnjih dana nismo naslušali i što sve nije napisano o Katoličkoj Crkvi i vjernicima. Nismo uočili da su se mjerodavne institucije za zaštitu raznih prava i ravnopravnosti zabrinule i da su reagirale. Koliko samo uvreda, neistina, prozivanja i ponižavanja. Slušali smo od visokih dužnosnika naše zemlje o tome da se vjernici ne smiju očitovati o nekim pitanjima u odgoju i obrazovanju, pa čak i da roditelji nemaju pravo na to; razni su ljudi
} 
razdoblje komunističke ideologije) kardinal Bozanić doprinio je jačanju fantazije o tadašnjoj vlasti kao komunističkoj vlasti koja širi komunističku ideologiju i, ne prihvaćajući kršćanski svjetonazor, Hrvatsku želi odvesti u moralnu dekadenciju (usp. Herzog 2015:185). Time je Bozanić antagonizam koji je postojao među građanima zbog oprečnih stavova nastalih u vrijeme rasprave oko medicinski potpomognute oplodnje dodatno ojačao uvođenjem podjele na one koji podržavaju retoriku prošlog režima i na one koji se toj retorici protive, odnosno na "komuniste" i "vjernike", i ta će podjela $\mathrm{s}$ vremenom sve više jačati, otežavati diskurzivne borbe i skretati raspravu k biopolitičkoj borbi protiv gay osoba kao prijetnje naciji i čovječanstvu. A kada se društvene borbe usmjere protiv određene skupine kao "biološkog referenta, ta se skupina nalazi pred ozbiljnom preprekom" (Laclau i Mouffe 1985:132).

Upravo se to dogodilo u vrijeme rasprave oko uvođenja definicije braka u Ustav RH kada je podijeljenosti društva u Hrvatskoj bila na svom vrhuncu. Još 2012. godine udruga Zagreb Pride izradila je Prijedlog Zakona o životnom partnerstvu i predstavila ga Ministarstvu uprave koje je bilo nadležno za pripremu završnog teksta Prijedloga Zakona kojim bi se reguliralo područje obiteljskog života istospolnih parova. U rujnu 2012. godine formirana je Radna skupina za izradu Zakona o registriranom (životnom) partnerstvu u kojoj su sudjelovali i članovi udruga civilnog društva, pa tako i Zagreb Pridea. Provocirajući teme poput braka i obitelji, a koje su temeljni dio heteronormativnog sustava vrijednosti, nova Vlada i udruge koje su zahtijevale jednaka prava za LGBTIQ osobe, navukli su tada na sebe gnjev Katoličke crkve i klera ${ }^{11}$ i izazvali paniku o budućnosti

predstavljajući se kao stručnjaci nastupali pokazujući veliko nepoznavanje odnosa Crkve i znanosti, Crkve i zdravstvene skrbi, Crkve i njezine uloge u demokraciji i civilnome društvu. Retorika je to koja seže duboko u vrijeme nedavne prošlosti." http://www. jutarnji.hr/foto-bozanic-porucio-milanovicu---spolni-odgoj-pitanje-je-svjetonazora--ane-higijene--/1074584/ (pristup 1. 2. 2016.).

${ }^{11}$ Napetost odnosa između Vlade i Crkve raste tijekom čitave 2012. godine, a obje strane tomu su doprinosile bez zadrške. Na božićnoj misi 2012. godine kardinal Bozanić prozvao je Vladu optužbom da "razara čovjeka i unesrećuje Hrvatsku" (http://www.vecernji. hr/hrvatska/kardinal-bozanic-ova-vlast-razara-covjeka-i-unesrecuje-hrvatsku-488840, pristup 12. 2. 2016.). Željko Jovanović, tadašnji ministar znanosti, obrazovanja i sporta, početkom siječnja 2013. godine javno je izjavio da "Biskupi lažu” kada uvjeravaju građane 
nacije. Budući da su prije rasprave o Zakonu o životnom partnerstvu odnosi između antagonističkih strana već bili zategnuti zbog sveukupne rasprave oko uvođenja novih zakona, dugotrajni verbalni rat između "Vlade i Crkve" na kraju je rezultirao uvođenjem ustavne definicije braka 2013. godine.

Zbog prijetećeg momenta koji je pripisan 'rodnoj ideologiji' - koju se u 'znanstvenim' krugovima bliskima Crkvi čak nastoji povezati s marksizmom i tako dodatno demonizirati ${ }^{12}-\mathrm{i}$ zbog straha i zabrinutosti oko "stabilnosti i opstanka društva", ${ }^{13}$ mobiliziran je velik broj konzervativnih udruga, konzervativnih političkih stranaka i pojedinaca vjernika kojima je povjerena zadaća zaštite tradicionalne obitelji kao "temeljne zajednice društva" ${ }^{14} \mathrm{~S}$ ciljem zaštite tradicionalne obitelji, udruga $\mathrm{U}$ ime obitelji i njezini simpatizeri u svibnju 2013. godine ${ }^{15}$ pokreću akciju prikupljanja potpisa građana za referendum o ustavnoj definiciji braka.

Građansku opoziciju inicijativi U ime obitelji pokreće Zagreb Pride koji saziva sastanak s predstavnicima civilnog društva i apelira da se kroz javne rasprave i medijsku kampanju krene u borbu protiv referenduma. U tu svrhu organizira se savez Građani glasuju protiv, u koji se uključilo 88 organizacija, grupa i inicijativa te velik broj javnih osoba, posebno iz kulturnih krugova koje apeliraju na građane da se glasanjem "protiv" na referendumu odupru jačanju i širenju mržnje prema drugim i drugačijim

o štetnosti zdravstvenog odgoja, što su prenijele brojne novine i portali (Novi list, Jutarnji list, Večernji list, 24 sata, index.hr, dnevno.hr, tportal.hr: http://www.tportal.hr/vijesti/ hrvatska/235235/Biskupi-lazu-a-s-takvima-ja-ne-razgovaram.html, pristup 12. 2. 2016.). Nakon toga Crkva uzvraća udarac, pa u Jutarnjem listu od 15. siječnja 2013. možemo pročitati kako "Crkva ne odustaje od borbe", a u Globusu da "Ustanak počinje. Akcijski plan nadbiskupa Bozanića: od 1. veljače 2013 svećenika u 1600 župa uz pomoć 4000 redovnika i redovnica i 1000 volontera počet će žestoku kampanju protiv Vlade: svaki dan organizirat će javne tribine protiv zdravstvenog odgoja i gay brakova" (http://globus. jutarnji.hr/hrvatska/specijalni-izvjestaj-iz-kardinalove-palace, pristup 12. 2. 2016.).

12 Vidi kod: Matić i Koprek 2014.

${ }^{13}$ Vidi Šljivić i Mlinarić 2016:121; http://referendumobraku.uimeobitelji.net/2013/11/19/ u-ime-obitelji-ustavna-zastita-braka-kao-zajednice-zene-muskarca/ (pristup 17. 2. 2016.).

${ }^{14}$ http://www.h-rast.hr/obiteljska-politika/ (pristup 17. 2. 2016.).

${ }^{15}$ Potpisi su se prikupljali diljem Hrvatske od 12. do 26. svibnja 2013. godine. 
osobama. Budući da su udruge vjernika u ovom slučaju sakupile dovoljno potpisa za održavanje referenduma, on je održan 1. prosinca 2013. godine. Pozivu se odazvalo 1436 163, odnosno 37,88\% građanki i građana; za ustavnu definiciju braka kao zajednice muškarca i žene izjasnilo se je $65,87 \%$ osoba, a protiv takve definicije $33,51 \%,{ }^{16}$ čime je sakupljen dovoljan broj glasova da se u Ustav i unese zahtijevana promjena. Iako ovakav ishod možemo tumačiti kao neuspjelu dislokaciju heteronormativnog sustava vrijednosti i hegemonije heteroseksualnog diskursa, treba imati na umu postulat koji iznose Laclau i Mouffe o tome da je svaki poredak diskursa nestabilan sustav i koliko je hegemonijski diskurs spomenutim događajima dislociran moći ćemo reći tek kroz nešto dulje razdoblje. Valja imati na umu da je nedugo nakon upisivanja definicije braka u Ustav, u srpnju 2014. godine, izglasan, uz aplauz u Saboru, Zakon o životnom partnerstvu ${ }^{17}$ koji je po nekima jedan od najboljih zakona toga tipa u regiji (Moss 2014:228), što znači da uvijek nastaju nove fronte destabilizacije hegemonijskog diskursa.

Kao što smo vidjeli u navedenom primjeru, a što kao drugi postulat svoje teorije diskursa navode Laclau i Mouffe, diskurs se oblikuje kroz hegemonijske borbe koje se ne vode samo na političkoj nego i na moralno-intelektualnoj fronti kako bi se uspostavilo političko ali i moralno-intelektualno vodstvo određenog diskursa koji će tada postati hegemonijski.

Diskurs se širi i učvršćuje artikulacijom koja se tumači kao praksa koja uspostavlja relacije, odnose među diskurzivnim elementima i koja izaziva međusobnu modifikaciju njihova identiteta (Torfing 2005:15). Da u slučaju hegemonijske borbe nije riječ samo o političkoj nego ponekad i mnogo više o moralno-intelektualnoj borbi u kojoj će prevladati i određene moralne vrijednosti i određeni znanstveni argumenti, posebno je bilo vidljivo neposredno prije referenduma o braku. Tada su u medijima i u javnom prostoru na temu braka nastupale brojne osobe s duhovne i intelektualne scene, znanstvenici i teolozi izlažući u ime svoje struke i/ili u svoje osobno

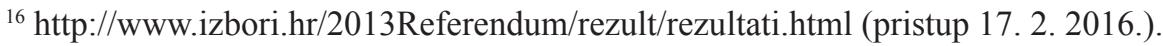

${ }^{17}$ Zakon je donesen na 13. sjednici 15. srpnja 2014. sa 89 glasova "za” (SDP, HNS, IDS, HSU, Laburisti, SDSS, manjine, nezavisni) i 16 "protiv" (HDZ, HDSSB, HSS, HSP AS).
} 
ime argumente za ili protiv određenog razumijevanja braka. ${ }^{18}$ Upravo se tako omogućuje širenje i učvršćivanje diskursa artikulacijom. Npr. diskurs koji je zastupao tradicionalnu definiciju braka kao zajednicu žene i muškarca uspostavljao je relaciju s kršćanstvom i kršćanskim moralnim vrijednostima, sa znanstvenim teorijama utemeljenim na esencijalizmu i naturalizmu i s nacionalnim sentimentom, a koji u Hrvatskoj imaju dugu tradiciju i veliku snagu mobilizacije javnosti (Hodžić i Bijelić 2014; Đurin

${ }^{18}$ Možda su još i bolji primjer moralno-intelektualne borbe događaji koji su se odvijali u vrijeme rasprave o uvođenju zdravstvenog odgoja u škole, kada su osobe duhovnog zvanja svoje stavove ojačavale znanstvenim argumentima i agresivno kritizirajući znanstvenike drugačijih stavova čiji se znanstveni ugled na razne načine pokušavao diskreditirati. Jedan od primjera jest članak koji je 9. siječnja 2013. godine pod naslovom Pederi i lezbe upropastit će nam Hrvatsku izašao u Slobodnoj Dalmaciji. Adalbert Rebić, svećenik i sveučilišni profesor, tamo daje svoj komentar na rezultate ankete kojom se ispitivalo javno mišljenje o uvođenju cjelokupnoga zdravstvenog odgoja u škole i relativizira i diskreditira stručnost Aleksandra Štulhofera, profesora na Filozofskom fakultetu, predstojnika Katedre za seksologiju, koji je koautor spornog modula o spolnom odgoju: "Ako pratite ankete koje idu uživo preko televizije i radija, uvidjet ćete da je više od 80 posto građana protiv predloženog seksualnog odgoja. Više je stvarno besmisleno upozoravati na to da se i Hrvatsku pokušava uklopiti u globalnu urotu pedera, homoseksualaca, lezbi i drugih osoba devijantnog seksualnog ponašanja koji svoje nazore pokušavaju nametnuti svima. Tako nam sada razni Štulhoferi, pederi i lezbe hoće nametnuti svoj manjinski seksualni moral koji će upropastiti društvo" (http://www.crol.hr/index.php/politika-aktivizam/4604adalbert-rebi-hrvatska-e-se-teko-oduprijeti-pederskoj-uroti-sp-355, pristup 11. 5. 2013.). $\mathrm{Na}$ taj primjer nadovezuju se događaji koji su se odvijali krajem siječnja 2013. godine kada je u organizaciji Centra za obnovu kulture i građanske udruge Vigilare (čija je misija, između ostalog, "promicanje konzervativnih društvenih vrjednota i kulture života") na turneju po Hrvatskoj iz Amerike došla Judith Reisman. Reisman je na poziv HDZ-a održala predavanje i u Hrvatskom saboru, gdje je političarima govorila o štetnosti spolnog odgoja za djecu, održala je javna predavanja na fakultetima u Zadru i Zagrebu, organizirano je i sučeljavanje između nje i Aleksandra Štulhofera. Iako su je njezini domaćini predstavljali kao moralno-intelektualni autoritet po pitanjima spolnog odgoja i seksualnosti, Reisman je naišla na negodovanje velikog djela hrvatske intelektualne scene te studenata i profesora na fakultetima na kojima je održala izlaganje. No, ni Štulhofer u toj borbi nije prošao bez 'povreda'. Njega je Reisman osudila za znanstvenu suradnju s pedofilima i kao simpatizera pedofilije, i u jednom se trenu gotovo čitav njegov znanstveni rad (moralno) relativizira, a njegov kredibilitet znanstvenika dolazi u pitanje zbog čega se obratio Hrvatskom helsinškom odboru "s molbom da se zaštite njegova temeljna ljudska prava, ljudsko dostojanstvo, te intelektualni i profesionalni dignitet od grubih javnih nasrtaja" (https:// www.hho.hr/izjava-br-32013-o-slucaju-stulhofer/, pristup 11. 5. 2013.). 
2012; Herzog 2015; Kahlina 2012; Moss 2014; Prlenda 2004; Ramet 1999; Škokić 2011a; Šljivić i Mlinarić 2016; Vuletić 2003, 2004), dok je diskurs koji se je borio za inkluzivnu definiciju braka artikulirao s građanstvom i građanskim slobodama, demokracijom i vrijednostima koje se vezuju uz politike Europske unije poput tolerancije, slobode, jednakosti, vladavine prava itd. Budući da je diskurs koji je zastupao tradicionalnu definiciju braka uspostavio relaciju među dominantnim diskurzivnim elementima s kojima se identificira većina građana (kršćanski moral, esencijalističko i naturalističko tumačenje nacionalnog identiteta), uspio se izboriti i za dominantnu političku poziciju koja se manifestirala u rezultatima referenduma i koja je dovela do upisivanja tradicionalne definicije pojma braka u Ustav RH. ${ }^{19}$ Ono što možemo uočiti kroz ovaj primjer jest da nije uvijek vladajuća politička elita ta koja stvara hegemonijski diskurs ili ima moć nad njime. Svaki diskurs koji u nekom trenutku u vremenu postane hegemonijski, ima svoj vlastiti život i svoje vlastite zakonitost, često nastale spletom okolnosti (Laclau i Mouffe rekli bi kontingentnošću), a hegemoniju postiže onaj diskurs odnosno "artikulacija koja uspije iznaći princip po

\footnotetext{
${ }^{19}$ Naravno da je u analize društvenih događaja nužno uključiti i ekonomski moment koji je itekako važan za razumijevanje cjelokupnog stanja, no, kako navode Howarth i Stavrakakis (2000:5), društvo je simbolički poredak u kojem se društveni antagonizmi i strukturalne krize ne mogu reducirati, npr., na klasne razlike determinirane ekonomskim procesima. Budući da u ovom članku nije riječ o stvarnoj diskurzivnoj analizi događaja nego se neki događaji koriste kako bismo primjerom objasnili postulate teorije diskursa, sama analiza kako je prikazana ovdje ostaje manjkava. Ipak ćemo skrenuti pozornost na to da mnogi autori upozoravaju kako je razvoj kapitalističkog tržišta povezan s pitanjima vezanima uz homoseksualnost i obitelj (Šljivić i Mlinarić 2016:104). Danijela Dolenec (2014) upozorava na povezanost nezadovoljstva nižih društvenih klasa koje nastaje zbog nedovoljne zaštite radnika pred kapitalom i pojačane diskriminacije u društvu jer se "bazen radničkog nezadovoljstva uz nevelik napor desnih političkih aktera prelijeva u diskriminatorne politike koje socioekonomske probleme prebacuju na teren identitetskih borbi. U britanskom kontekstu kraja sedamdesetih to se odnosilo na fašističke interpretacije rasnih odnosa, kao i tematizaciju imigracije kao 'prijetnje našem načinu života'. U rasno i etnički homogenoj Hrvatskoj primarno polje diskriminatornih identitetskih politika su seksualne manjine i ženska reproduktivna prava, ali princip je isti." Protuprosvjed Povorci ponosa 2005. godine upravo potvrđuje tu tezu - tada su se prosvjednici bunili zbog navodnih visokih troškova Povorke ponosa, noseći transparente sa sljedećim natpisima: “penziću 50 kn dnevno, pederu 250 kn za paradu”, “Hrvatska, za Mungose nemaš, za pederluk imaš", "paradirajte o svom trošku” itd.
} 
kojem će se tumačiti prošli, sadašnji i budući događaji i koja uspije osvojiti srca i umove građana. Svaka takva hegemonijska artikulacija koja unificira diskurzivni prostor uvijek sadrži u sebi element ideološke totalizacije" (Torfing 2005:15).

Upravo zbog ideološke totalizacije, hegemonijska artikulacija značenja i identiteta intrinzično je povezana s konstrukcijom socijalnih antagonizama, postuliraju treću točku svoje teorije Laclau i Mouffe. Naime, oni polaze od pretpostavke da društvo nikada ne uspijeva u potpunosti biti društvo jer je svaki dio društva prožet ograničenjima koja mu onemogućuju da se konstituira kao objektivna realnost. Ta su ograničenja dio društvenog samog. Stoga društveno postoji tek kao pokušaj da se konstruira društvo (Laclau i Mouffe 1985:125) koje nikada ne može postići svoju cjelovitost i puninu, a antagonizmi su upravo pokazatelji toga. Također, antagonizmi se javljaju jer društveni agensi nisu sposobni postići svoj puni identitet zbog Drugoga koji “me sprečava da budem u potpunosti ono što jesam" (ibid.:125).

Antagonizmi nastaju logikom ekvivalencije i razlike. Logika ekvivalencije djeluje tako da proizvodi polaritete i političke granice, centar i marginu među oprečnim društvenim taborima, a logika razlike omekšava granice među oprečnim strujama i nastoji integrirati one s margine društva u većinsko društveno tijelo. Nemogućnost društvene zajednice da prihvati kao dio sebe neku društvenu skupinu upućuje na to da svaka društvena struktura ima granice, odnosno limite. Antagonizmi su pokazatelji tih limita, smatraju Laclau i Mouffe. U svakom konkretnom slučaju analize diskursa, socijalni se antagonizam pokazuje kroz produkciju političkih granica, a borba oko toga što i tko je uključen i tko isključen iz hegemonijskog diskursa jest stalna i centralni je dio politike. Nadalje, karakteristika je demokratskih diskurzivnih borbi da se one istodobno odvijaju na više različitih polja unutar političkog prostora, a mnoštvo praksi koje iz toga nastaju ne iscrpljuje svu realnost onih koji sudjeluju u njima (ibid.:132). Drugim riječima, mogli bismo reći da se oni koji sudjeluju u diskurzivnim borbama mogu nalaziti na margini društva kao dio jedne društvene skupine ili po nekom svom identitetu, ali nisu marginalizirani ili isključeni iz društva u sveukupnosti svojih akcija i/ili identiteta. 
No, postoje i primjeri borbe kada to nije slučaj i kada su diskurzivne borbe kao političke akcije otežane ili nemoguće, kao u slučajevima kada je politički prostor oštro podijeljen u dva antagonistička tabora između kojih nema mogućnosti povezivanja, odnosno omekšavanja granice nastale logikom razlike, ni mogućnosti uključivanja margine društva u većinsko društveno tijelo. To je posebno slučaj kada su političke borbe usmjerene protiv određene skupine ljudi kao bioloških subjekata (ibid.:132). Tada borbe "ignoriraju specifičnost političkih prostora u kojima se pojavljuju i drugi demokratski antagonizmi" (ibid.:132) i reduciraju višestrukost demokratskih borbi na borbu protiv "jednog i jasno definiranog neprijatelja" (ibid.:131) - 'biološkog Drugog' koji se vidi kao prijetnja opstanku društva. Kao fatalan primjer potpune separacije unutar sustava Laclau i Mouffet navode milenarističke pokrete koji su podijelili društvo u dva odvojena tabora: seljačku kulturu koja je predstavljala pokret i urbanu kulturu koja je opisana kao utjelovljenje zla. Svaka od tih kultura bila je potpuna negacija one druge i kada je krenuo milenaristički ustanak, sve što je imalo bilo kakve diskurzivne veze s gradom uništeno je bez ikakve selekcije jer nije postojao diskurs koji bi unutar lanca ekvivalencije uspostavio razlike među elementima, nego su oni svi bez iznimke predstavljali zlo (ibid.:130). Ovaj opis uvelike podsjeća na stanje u Hrvatskoj izazvano borbama oko toga koja će definicija braka ući u Ustav RH. Gay osobe tada su prikazivane kao biološki Drugi odgovoran za izumiranje nacije i kao prijetnja čovječanstvu. Jaka polarizacija koja se tada dogodila u Hrvatskoj podijelila je društvo na dva gotovo potpuno odvojena dijela između kojih su oslabljeni uvjeti potrebni za hegemonijske borbe koje bi rezultirale uključivanjem margine u društveno tijelo. Reducirana je i mogućnost diskurzivnih borbi jer one pretpostavljaju postojanje više demokratskih antagonizama istodobno, odnosno više lanaca ekvivalencija. Takve su situacije samo korak od nestanka političkog prostora koji pruža uvjete potrebne za hegemonijske borbe i za uključivanje margine u društveno tijelo i samo korak od općeg nasilja nad gay osobama, kao što je pokazao nedavni primjer Čečenije,$^{20}$ ali, s druge strane, one omogućuju otvaranje novih prostora i načina političkog

\footnotetext{
${ }^{20} \mathrm{http}$ //www.crol.hr/index.php/politika-aktivizam/8639-macron-resetao-putina-oprogonu-gejeva-u-ceceniji (pristup 18. 7. 2017.).
} 
djelovanja u naizgled politički nemogućim okolnostima kao što i otvaraju mogućnost postojanja političke namjere u situacijama u kojima na prvi pogled ne postoje politički zahtjevi ugrožene margine. ${ }^{21}$

Posljednji postulat teorije diskursa jest opaska da antagonizmi rezultiraju stabilizacijom određenogdiskursa kojipostajehegemonijski. U spominjanom primjeru, tradicionalna definicija braka učvrstila je diskurs o heteroseksualnosti kao hegemonijski. No, kao što upozoravaju Laclau i Mouffe, ni jedan hegemonijski diskurs ne zadržava svoju hegemoniju trajno nego u nekom trenutku postaje dislociran. To se događa kada mu se suprotstave novi događaji koje ne može integrirati u sebe. Tada će se diskurzivni sustav srušiti i otvoriti prostor novim hegemonijskim borbama.

\section{UTJECAJ TEORIJE DISKURSA NA DRUŠTVENE I HUMANISTIČKE ZNANOSTI I NEKI OD PRIGOVORA TEORIJI DISKURSA}

Kako je osnovna ideja ovog članka predstavljanje poststrukturalističke teorije diskursa, ono ne bi bilo potpuno kada se ne bismo osvrnuli na njezine distinktivne jake i slabe strane.

U članku Discourse Theory: Achievements, Arguments and Challenges (2005) Jacob Torfing upozorava na dosadašnji doprinos teorije diskursa društvenim i humanističkim znanostima, polemizira s prigovorima koji se upućuju teoriji diskursa i navodi njezine slabe točke koje još čekaju da budu ojačane. Torfing smatra da je do sada analiza diskursa uspjela ostvariti značajan utjecaj na humanističke, društvene i političke znanosti. Razvila je "brojne sofisticirane koncepte i argumente koji pomažu u prevladavanju objektivističkih, redukcionističkih i racionalističkih predrasuda moderne društvene znanosti i njezinih teorija i radikalizirala je alternativne hermeneutičke pristupe naglašavajući ulogu diskursa i politika u oblikovanju društvenih, političkih i kulturalnih interpretacija (...) Koncepti i argumenti koje koristi analiza diskursa ne poklapaju se s modernističkim zahtjevima za konceptualnom jasnoćom i čvrstoćom jer

${ }^{21}$ Primjer diskurzivne političke borbe za prava gay osoba u naizgled nemogućim političkim uvjetima opisali su Sik Ying Ho i Kat Tat Tsang (2000:140 i dalje). 
ne proizlaze iz aksiomatskih pretpostavki višeg reda, nego se razvijaju u i kroz kontekstualnost s postojećim diskursima akademske i neakademske zajednice", navodi Torfing (2005:3-4). Za teoriju diskursa značenje je konstruirano unutarrelacijski, a relacije su predmet stalnih razmještanja i prijeloma. Osim toga, kako navodi Torfing, analiza diskursa doprinijela je kritičkoj obnovi nekih disciplina. To je potaknuto sve većim uviđanjem ispreplitanja jezika i politike u procesima društvenih promjena i zato teorija diskursa može ponuditi inovativan pristup studijima međunarodnih odnosa, studijima Europske unije i njezinih politika, istraživanju javne administracije i državne politike, istraživanju populizma, nacionalizma i eugenike, analizi masovnih medija, kulturnoj geografiji i urbanim studijima, između ostalog. Konačno, analiza diskursa uvjerila je mnoge teoretičare da obrate pozornost na nove pojmove kao što su paradigme znanja, oblikovanje identiteta te diskurzivna proizvodnja normi, vrijednosti i simbola, primjećuje Torfing.

Nadalje, David Howarth značajan doprinos teorije diskursa suvremenim društvenim i humanističkim istraživanjima vidi u tome što teorija diskursa, istražujući konkretne fenomene, ne samo da uspostavlja nove predmete istraživanja tako što propituje postojeće prikaze i teoretske okvire unutar kojih se ti fenomeni tumače, nego i propituje političke okolnosti unutar kojih se te teorije pojavljuju i unutar kojih djeluju (Howarth 2005:319). S obzirom na to da je svaki društveni fenomen specifičan, razumljivo je $\mathrm{i}$ da istraživanje svakoga takvog fenomena zahtijeva pristup koji i svojim teoretskim korpusom, i odabirom tekstovnog i netekstovnog materijala, odnosno različitih diskurzivnih formi koje će se analizirati, mora biti drugačiji od pristupa nekom drugom fenomenu. Pri istraživanju društvenih fenomena, cilj teorije diskursa nije samo ponuditi nove opise ili činjenice o specifičnom predmetu istraživanja, nego i pružiti nove interpretacije tako što će se uputiti na neke momente koji su ranijim dominantnim teoretskim pristupima ostali neotkriveni, ili pak tako što će se, artikulacijom alternativnih interpretacija, problematizirati postojeći prikazi određenog problema. Kao dobar primjer takvog doprinosa Howarth (2005:321) navodi interpretaciju orijentalističkog diskursa Edwarda Saida kojim se otvorio čitav novi set identiteta i fenomena za analizu i koji je doprinio otvaranju sasvim novog polja studija - studija podređenih skupina. 
Glede prigovora teoriji diskursa, jedan od najčešćih koje zapaža Torfing (2005:18) jest da teorija diskursa vodi u idealizam. Mnogi smatraju da tvrdnja o diskurzivnom karakteru svih društvenih značenja i identiteta vodi u poricanje nezavisnog postojanja stvarnosti. No teorija diskursa zapravo ne osporava tvrdnju realista da stvari postoje nezavisno od naše svijesti, misli i jezika. Kao što objašnjavaju Laclau i Mouffe: "Jedan potres ili cigla koja je nekomu pala na glavu događaji su koji bez sumnje postoje ili su mogući sada i ovdje, nezavisno od moje volje. Ali hoće li se neki objekt ili događaj objasniti u terminima 'prirodnog fenomena' ili kao 'znak božje volje i upozorenja’ ovisi o načinu kako je strukturirano diskurzivno polje. Ovdje se ne poriče da ti objekti postoje izvan naših misli nego da se oni ne mogu konstituirati kao objekti izvan diskurzivnih uvjeta postojanja" (Laclau i Mouffe 1985:108). Drugim riječima, teorija diskursa tek tvrdi da ništa ne slijedi iz samog postojanja stvari. Stvari same po sebi ne nose način svoje vlastite reprezentacije. Reprezentacija i značenje oblikuju se kroz simboličku upotrebu jezika. Nadalje, društvene forme koje čine stvari razumljivima nisu ni pasivne refleksije neke imanentne esencije iskustvenih objekata koje reduciraju objekt na misao o objektu. Prije su te društvene forme konstruirane u i kroz različite diskurse. Torfing (2005:18) to tumači kroz sljedeći primjer: određeni dio zemlje skupina biologa može konstruirati kao mjesto boravka neke ugrožene skupine, urbana populacija kao mjesto za rekreaciju, lokalni farmeri kao plodnu zemlju, itd. Ovaj primjer, smatra Torfing, nudi tri opaske koje pružaju daljnju ontološku kvalifikaciju pozicije teorije diskursa (ibid.:18). Prvo, diskurzivna konstrukcija kroz proces i u procesu diskurzivnog označivanja nastoji proizvesti stvari ili barem ojačati određene subjektivitete. Dakle, konstrukcija zemlje kao obradive površine konstruira određene ljude kao farmere. Drugo, stvari ne čekaju određeno značenje koje će im se urezati diskursom. Diskurzivne forme igraju aktivnu ulogu u konstruiranju onoga što označuju. Isto primjećuju i Judith Butler (1994) i Stuart Hall $(1996,1997)$ kada navode da subjekti nisu tek pasivni promatrači u stvaranju novih identiteta nego njihovo djelovanje prethodi i uvjetuje oblikovanje novih identiteta. Dakle, referent u terminima 'komad zemlje' retroaktivno se konstruira kroz diskurzivne forme koje će izdvojiti određenu stvar da bude označena. Treće, diskursi koji konstruiraju materiju kao predmet ispunjen značenjem neprestano se mijenjaju kroz dislokacije i društvene antagonizme, zaključuje Torfing. 
Druga primjedba na koju Torfing odgovara jest da se teorija diskursa sastoji od skupine nasumce i slučajno odabranih primjera iz relativističko-nihilističke košare. Argument za takvu tvrdnju temelji se na ideji da ako nema čvrstih temelja i ako je sve diskurzivno, nemoguće je obraniti bilo koji set tvrdnji o tome što je istinito, ispravno i dobro. Iako je premisa ovog argumenta ispravna, jer diskurzivna teorija drži da ne postoji nešto poput izvan-diskurzivne istine, morala ili etike, zaključak je pogrešan, smatra Torfing. Naime, teško ćemo se složiti s tvrdnjom da su sve tvrdnje jednako vrijedne. "Mi smo uvijek dio određenog diskursa koji nas opskrbljuje setom jasno određenih vrijednosti, standarda i kriterija po kojima sudimo je li nešto istinito ili lažno, ispravno ili neispravno, dobro ili loše" (Torfing 2005:19). Neki izvanjski entitet, sposoban uzdići se nad historijski kontingentne diskurse, mogao bi vidjeti sve režime istine koji se bore za uspostavu etičkih standarda kao jednako važeće. Za razliku od toga hipotetskoga izvanjskog entiteta, mi smo "vezani uz određeni diskurzivni okvir unutar kojeg definiramo i pregovaramo svoje kriterije oko toga što je istinito, ispravno i dobro. Kad bismo bili uhvaćeni u zamku kompletno unificiranog, zatvorenog i sebeproizvodećeg diskursa, mogućnost nekoga antagonističkog dijaloga između ljudi s različitim, diskurzivno uvjetovanim tvrdnjama istinitosti, bila bi nemoguća. Ali različite kulture, tradicije, i konteksti koji uvjetuju naše tvrdnje istinitosti neprestano se disartikuliraju i reartikuliraju kroz procese međusobnog učenja, političkih borbi i konflikata. Ni jedan diskurs ne može biti zaštićen od pobijanja i kontaminacije jer se njegove granice neprestano prekidaju i prekrojavaju" (ibid.:19). Spomenuti primjer rasprave oko braka u Hrvatskoj jest pokazatelj jednoga takvog pokušaja relativiziranja i redefiniranja postojećih režima istine $u$ kojem se instrumenti demokratskog sustava koriste za nedemokratske procedure. ${ }^{22}$

Još jedan problem na koji referira Torfing, a s kojim ćemo završiti, povezuje se s upitnošću statusa teorije diskursa kao eksplanatorne teorije. "Neki kritičari smatraju da teorija diskursa ne može ponuditi više od opisa artikulatornih praksi unutar i između različitih diskursa; da može razumjeti ali ne i objasniti društveni, politički i kulturni život neke zajednice ili

${ }^{22}$ Vidi Hodžić i Bijelić 2014. 
društva" (ibid.:19). No Torfing objašnjava na koji način teorija diskursa nastoji objasniti društvene događaje: teorija diskursa "ne smatra da je zadatak teoretičara društva da uspostavlja univerzalne zakone ili otkriva unutrašnje kauzalitete društvenih objekata. Umjesto toga, teorija diskursa nastoji opisati, razumjeti i objasniti kako i zašto se određene diskurzivne formacije konstruiraju, stabiliziraju i transformiraju. Kako bi otkrila nužne i dovoljne uvjete diskursa da se oblikuje i preoblikuje na određeni način, teorija diskursa uključuje kontekstualizirane koncepte kao što su dislokacija, hegemonija, socijalni antagonizmi" i "nastoji razumjeti i objasniti društvene fenomene kroz kontekstualizirane studije historijskih uvjeta u kojima diskursi nastaju i imaju efekta" (ibid.:19-20).

\section{ZAKLJUČAK}

Poststrukturalistička teorija diskursa u izvođenju se istraživanja vodi problemom koji istražuje. David Howarth (2005) uspoređuje teoriju diskursa s Foucaultovom tehnikom problematizacije (Foucault 1985). "Problematizacija započinje istraživanje fokusiranjem na neki etički ili politički problem u sadašnjosti, a zatim se posvećuje analizi historijskih i strukturalnih uvjeta koji su doveli do pojave toga problema tražeći istodobno sredstva za njegovu kritiku" (Howarth 2005:318). U slučaju ovog članka, problem na koji smo se fokusirali bio je rasprava o ustavnoj definiciji braka u Hrvatskoj i antagonizmi koji su nastali oko nje. Uputili smo i na to da je diskurzivna borba koja je nastala oko uvođenja definicije braka u Ustav dovela do biopolitičke borbe u kojoj konzervativne skupine građana pokušavaju reprezentirati gay osobe kao biološkog Drugog, odnosno kao prijetnju opstanku nacije i u skladu s time rade pritisak na biopolitiku države. No u ovom je članku izostala analiza historijskih i strukturalnih uvjeta koji su doveli do te rasprave, kao i njihova kritika, jer je namjera ovog članka bila kroz primjer rasprave o definiciji braka objasniti i približiti čitatelju temeljne postulate teorije diskursa, a ne analiza samog problema. Za kraj se možemo osvrnuti na neke od brojnih efekata koje su u društvu izazvale diskurzivna i biopolitička borba opisane u ovom radu.

S jedne strane, u 2013. godini zabilježen je povećan broj prekršajnih i kaznenih prijava protiv pojedinačnih osoba koje je pokrenula udruga 
Zagreb Pride zbog širenja mržnje prema LGBTIQ osobama u dva razdoblja: za vrijeme skupljanja referendumskih potpisa (svibanj - lipanj 2013.), kao i u završnom dijelu referendumske kampanje. ${ }^{23}$ Nadalje, istraživanje koje su nakon referenduma izradili Opačić i Jurčić pokazuje da je širenje negativnih stavova i mržnje prema LGBTIQ osobama za vrijeme referendumske kampanje ojačalo diskriminaciju i agresiju prema njima nakon održavanja referenduma. Nakon referenduma također rastu strah, tjeskoba i zabrinutost za vlastiti život osoba LGBTIQ orijentacije u Hrvatskoj (Opačić i Jurčić 2014:45-6).

S druge strane, uplitanje Crkve u javne politike, stvaranje paranoidnog straha od ideološke manipulacije i raspirivanje mržnje prema LGBTIQ zajednici koju u vrijeme rasprava udruge vjernika i kler opisuju kao prijetnju opstanku društva i obitelji, izazvalo je revolt i mobilizaciju velikog djela građanstva, što je bilo vidljivo u masovnoj podršci Povorci ponosa 2013. godine. Te je godine prema procjenama organizatorica u Povorci pod sloganom “Ovo je zemlja za sve nas" sudjelovalo preko 15000 građana i građanki, među kojima je bio i velik broj osoba iz javnog, kulturnog, političkog, akademskog i umjetničkog života Republike Hrvatske, a koji su sudjelovanjem u Povorci željeli iskazati svoje suosjećanje i naklonost homoseksualnim osobama te podršku njihovu nastojanju da steknu jednaka prava na brak kao i svi ostali građani. Drugim riječima, diskurzivna borba oko definicije pojma braka dovela je do toga da brojni građani koji nisu imali dotad jasno artikuliran stav o homoseksualnim osobama, taj stav izgrade.

${ }^{23}$ Zagreb Pride. Godišnji izvještaj za 2013. godinu. http://www.zagreb-pride.net/new/ wp-content/uploads/2017/04/Godi\%C5\%A1nji-izvje\%C5\%A1taj-Zagreb-Pride_2013. pdf (pristup 11. 5. 2017.). 


\section{LITERATURA}

BARTHES, Roland. 1979. Književnost, mitologija, semiologija. Beograd: Nolit.

BELSEY, Catherine. 2002. Postsructuralism: A Very Short Introduction. Oxford: Oxford University Press.

BERLANT, Lauren i Michael WARNER. 1998. "Sex in Public”. Critical Inquiry, vol. 24/2:547-566. https://doi.org/10.1086/448884

BOŽIĆ VRBANČIĆ, Senka. 2009. "Rasprava: diskurzivne teorije i pitanje europskog identiteta”. Etnološka tribina, vol. 38/31:9-39. http://hrcak.srce.hr/34625

BUTLER, Judith. 1994. "Gender as performance: an interview with Judith Butler". Radical Philosophy, vol. 67:32-37.

DOLENEC, Danijela. 2014. "Veliki zaokret udesno?”. H-Alter, 30. svibnja. http://www.halter.org/vijesti/veliki-zaokret-udesno (pristup 12. 5. 2017.).

DOTA, Franko. 2011. “Zašto je Stonewall važan: prije i poslije pobune! [Predgovor hrvatskom izdanju].” U CARTER, David. 2011. Stonewall. Pobuna koja je rasplamsala gej revoluciju.. Zagreb: Zagreb Pride, XI-XXI.

ĐURIN, Sanja. 2012. “O politici seksualnosti u Hrvatskoj devedesetih, o diskursima koji su je oblikovali i o njezinim simptomima danas". Narodna umjetnost, vol. 49/2:33-51. https://hrcak.srce.hr/93659

ECO, Umberto. 1973. Kultura, informacija, komunikacija. Beograd: Nolit.

FOUCAULT, Michel. 1985. The use of pleasure. New York: Vintage Books.

HALL, Stuart. 1996. "Introduction: Who Needs 'Identity"”. U Questions of Cultural Identity, ur Stuart Hall i Paul du Gay. London: Sage, 1-17.

HALL, Stuart, ur. 1997. Representation: Cultural Representations and Signifying Practices. London: Sage.

HERZOG, Dagmar. 2015. Seksualnost u Europi 20. stoljeća. Zagreb: Zagreb Pride.

HO, Sik Ying i TSANG, Ka Tat. 2000. "Beyond being gay: the proliferation of political identities in colonial Hong Kong". U Discourse theory and political analysis: identities, hegemonies and social change, ur. David Howarth, Aletta J. Norval i Yannis Stavrakakis. Manchester: Manchester University Press, 134-151.

HODŽIĆ, Amir i Nataša BIJELIĆ. 2014. Neokonzervativne prijetnje seksualnim $i$ reproduktivnim pravima u Europskoj Uniji. Zagreb: CESI. http://www.cesi.hr/ attach/_n/neokonzervativne_prijetnje_srp_u_eu.pdf(pristup 1. 2. 2016.).

HOWARTH, David. 2005. “Applying Discourse Theory: the Method of Articulation”. U Discourse theory in European politics: identity, policy and governance, ur. David Howarth i Jacob Torfing. New York: Palgrave, 316-349. 
HOWARTH, David. 2013. Poststructuralism and After. Structure, Subjectivity and Power. London: Palgrave Macmillan.

HOWARTH, David i Yannis STAVRAKAKIS. 2000. "Introducing Discourse Theory and Political Analysis". U Discourse theory and political analysis: identities, hegemonies and social change, ur. David Howarth, Aletta J. Norval i Yannis Stavrakakis. Manchester: Manchester University Press, 1-23.

IVAS, Ivan. 1988. Ideologija u govoru. Zagreb: Hrvatsko filozofsko društvo.

KAHLINA, Katja. 2012. Sexual Politics of Belonging: Sexual Identities, Nationalism, and Citizenship in Post-Yugoslav Croatia. Budapest: CEU.

LACLAU, Ernesto. 2000. "Foreword". U Discourse theory and political analysis: identities, hegemonies and social change, ur. David Howarth, Aletta J. Norval i Yannis Stavrakakis. Manchester: Manchester University Press, x-xi.

LACLAU, Ernesto i Chantal MOUFFE. 1985. Hegemony and Socialist Strategy. Towards a Radical Democratic Politics. London: Verso.

MATIĆ, Domagoj i Ivan KOPREK. 2014. "Bioetička i ideološka pozadina 'rodne teorije"”. Obnovljeni život, vol. 69/3:381-393.

MOSS, Kevin. 2014. "Split Europe: Homonationalism and Homophobia in Croatia". U LGBT Activism and the Making of Europe. A Rainbow Europe?, ur. Phillip M. Ayoub i David Paternotte. Basingstoke: Palgrave Macmillan, 212-232.

MOSSE, George L. 1988. Nationalism and Sexuality: Middle-Class Morality and Sexual Norms in Modern Europe. Madison: University of Wisconsin Press.

OPAČIĆ, Tamara i Marko JURČIĆ. 2014. Istospolne obitelji $i$ životna partnerstva u Hrvatskoj uoči i nakon referenduma o ustavnoj definiciji braka. Istraživački izvještaj. Zagreb: Cenzura Plus.

PETROVIĆ, Duško. 2011. “Analiza političkih aspekata studentske blokade Filozofskoga fakulteta u Zagrebu: metoda i strategija studentske blokade". Studia ethnologica Croatica, vol. 23:327-347. http://hrcak.srce.hr/74752

PRLENDA, Sandra. 2004. "Young, Religious, and Radical". U Ideologies and National Identities. The Case of Twentieth-Century Southeastern Europe, ur. John Lampe i Mark Mazower. Budapest: CEU Press, 82-105.

RAMET, Sabrina P., ur. 1999. Gender Politics in the Western Balkan. Women and Society in Yugoslavia and the Yugoslav Successor States. Pennsylvania: Pennsylvania State University Press.

ŠKILJAN, Dubravko. 1980. Pogled u lingvistiku. Zagreb: Školska knjiga.

S̆KILJAN, Dubravko. 1988. Jezična politika. Zagreb: Naprijed.

ŠKILJAN, Dubravko. 1998. Javni jezik. Beograd: XX vek.

ŠKOKIĆ, Tea. 2011a. "Can Croatia Swallow It? The Lack of Freedom of Sexual Expression". U Love and Sexuality. Anthropological, Cultural and Historical 
Crossings, ur. Slađana Mitrović i Alja Adam. Zagreb: Centar za ženske studije, Red Athena University Press, 131-143.

ŠLJIVIĆ, Dragan i Martin MLINARIĆ. 2016. "Sexual Othering and Democracy in postYugoslav Societies: A Comparison of Dveri and U ime obitelji”. U Minorities under Attack: Othering and Right-Wing Extremism in Southeast European Societies, ur. Sebastian Goll, Martin Mlinarić i Johannes Gold. Wiesbaden: Harrassowitz Verlag, $103-128$.

TORFING, Jacob. 2005. "Discourse Theory: Achievements, Arguments, and Challenges". U Discourse theory in European politics: identity, policy and governance, ur. David Howarth i Jacob Torfing. New York: Palgrave, 1-32.

VULETIĆ, Dean. 2003. “Gay i lezbijska povijest Hrvatske: od Drugog svjetskog rata do 1990.”. Gordogan, vol. I/1:106-121.

VULETIĆ, Dean. 2004. “Gay i lezbijska povijest Hrvatske: devedesete godine - između autoritarnosti i liberalizma”. Gordogan, vol. II/2-3:138-156.

ZAGREB PRIDE. 2013. Godišnji izvještaj. http://www.zagreb-pride.net/new/wp-content/ uploads/2017/04/Godi\%C5\%A1 nji-izvje\%C5\%A1taj-Zagreb-Pride_2013.pdf (pristup 11. 5. 2017.).

\section{INTERNETSKI IZVORI}

CROL. 2017. “Macron 'rešetao' Putina o progonu gejeva u Čečeniji”. CROL, LGBT news portal, 31. svibnja. http://www.crol.hr/index.php/politika-aktivizam/8639-macronresetao-putina-o-progonu-gejeva-u-ceceniji (pristup 18. 7. 2017.).

CroL/Slobodna Dalmacija, 2013. “Adalbert Rebić: 'Hrvatska će se teško oduprijeti pederskoj uroti"”. CROL, LGBT news portal, 9. siječnja. http://www.crol.hr/ index.php/politika-aktivizam/4604-adalbert-rebi-hrvatska-e-se-teko-oduprijetipederskoj-uroti-sp-355 (pristup 11. 5. 2013.).

HINA, 2012. “Bozanić Milanoviću: 'Spolni odgoj pitanje je svjetonazora!’”. Jutarnji. $h r, 25$. prosinca. http://www.jutarnji.hr/foto-bozanic-porucio-milanovicu---spolniodgoj-pitanje-je-svjetonazora--a-ne-higijene--/1074584/ (pristup 1. 2. 2016.).

“Izjava br. 3/2013: o slučaju Štulhofer”. 2013. Hrvatski helsinški odbor za ljuska prava. https://www.hho.hr/izjava-br-32013-o-slucaju-stulhofer/ (pristup 11. 5. 2013.).

MILKOVIĆ, Ante. 2013. "Specijalni izvještaj iz kardinalove palače”. globus.jutarnji. hr. http://globus.jutarnji.hr/hrvatska/specijalni-izvjestaj-iz-kardinalove-palace (pristup 12. 2. 2016.).

“O programu zdravstvenoga odgoja u školama”. 2012. Hrvatska biskupska konferencija. http://www.hbk.hr/1_z_odgoj.pdf (pristup 9. 5. 2017.).

“Obiteljska politika”. [s. a.]. Hrast.hr. http://www.h-rast.hr/obiteljska-politika/ (pristup 17. 2. 2016.). 
“Ocjena prvih 112 dana nove vlasti. Platforma 112, za hrvatsku vladavine prava”. 2012. Documenta, centar za suočavanje s prošlošću. https://www.documenta.hr/assets/ files/objave/2012\%2004/2012.04.06_Platforma112.pdf (pristup 10. 5. 2017.).

"Okrugli stolovi i rasprave 'Autorasizam, kriza liberalne demokracije i iščezavanje ljevice'”. 2016. Nezavisni sindikat znanosti i visokog obrazovanja, 12. prosinca. http://www.nsz.hr/novosti-i-obavijesti/okrugli-stolovi-i-rasprave/autorasizamkriza-liberalne-demokracije-i-iscezavanje-ljevice/ (pristup 12. 5. 2017.).

PAVIČIĆ, Darko. 2012. Kardinal Bozanić: Ova vlast razara čovjeka i unesrećuje Hrvatsku!". Vecernji.hr, 18. prosinca. http://www.vecernji.hr/hrvatska/kardinalbozanic-ova-vlast-razara-covjeka-i-unesrecuje-hrvatsku-488840 (pristup 12. 2. 2016.).

"Referendum, 1. prosinca 2013. Potpuni službeni rezultati državnog referenduma". 2013. Državno izborno povjerenstvo Republike Hrvatske. http://www.izbori. $\mathrm{hr} / 2013 R e f e r e n d u m /$ rezult/rezultati.html (pristup 17. 2. 2016.).

"U ime obitelji: ustavna zaštita braka kao zajednice žene i muškarca". 2013. U ime obitelji. Referendum o braku, 19. studenoga. http://referendumobraku.uimeobitelji. net/2013/11/19/u-ime-obitelji-ustavna-zastita-braka-kao-zajednice-zenemuskarca/ (pristup 17. 2. 2016.). 
Sanja Đurin

\section{POSTSTRUCTURALIST DISCOURSE THEORY THROUGH DISCUSSION ON THE INTRODUCTION OF THE CONCEPT OF 'MARRIAGE' IN THE CROATIAN CONSTITUTION}

The discourse theory still occupies a rather marginal position and faces considerable scepticism in the Croatian academic community. By examining the core arguments of the discourse theory, this paper aims to transform the present attitude. The discourse theory assumes that every linguistic and non-linguistic production (including speeches, reports, manifestos, historical events, ideas, interviews, archives, policies, documents, organizations and institutions, narratives in museums, motion pictures, etc.) represents discursive forms which constitute a 'discourse' and its 'reality'. Based on Foucault's theoretical legacy, and by elaborating the concept of discourse as defined in Ernesto Laclau and Chantal Mouffe's Hegemony and social strategy, the discourse theory uses discursive forms to "describe, understand, and explain how and why particular discursive formations were constructed, stabilized and transformed" (Torfing 2005:19). Recent discussion on the definition of marriage in Croatia and its introduction in the Constitution of the Republic of Croatia serves as a particular and specific example which has allowed the examination of the main aspects of the concept in this paper.

Keywords: poststructuralist discourse theory, marriage, referendum, Croatian Constitution, Law on Life Partnership, biopolitics

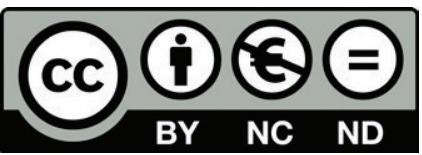

Articles published in this journal are Open Access and can be distributed under the terms and conditions of the Creative Commons license Attribution-NonCommercial-NoDerivatives 4.0 (http://creativecommons.org/licenses/by-nc-nd/4.0/) 